\title{
The Effect of Active and Passive Recovery of Weight Training on the Volleyball Smash Performance
}

\author{
Dindin Abidin,"*, Memet Muhamad ${ }^{1}$, Johansyah Lubis², Ujang Maman ${ }^{3}$, Sudirah $^{4}$ \\ ${ }^{1}$ Teacher Training and Education Faculty, Islamic University 45 (UNISMA), Bekasi, 17113, Indonesia \\ ${ }^{2}$ Sports Science Faculty, State University of Jakarta, 13220, East Jakarta, Indonesia \\ ${ }^{3}$ Science and Technology Faculty, State Islamic University Syarif Hidayatullah Jakarta, 15412, Tangerang Selatan, Indonesia \\ ${ }^{4}$ Faculty of Social and Political Sciences, Universitas Terbuka, Jakarta, Indonesia
}

Received January 14, 2021; Revised March 2, 2021; Accepted April 18, 2021

\section{Cite This Paper in the following Citation Styles}

(a): [1] Dindin Abidin, Memet Muhamad, Johansyah Lubis, Ujang Maman, Sudirah, "The Effect of Active and Passive Recovery of Weight Training on the Volleyball Smash Performance," International Journal of Human Movement and Sports Sciences, Vol. 9, No. 3, pp. 513 - 521, 2021. DOI: 10.13189/saj.2021.090317.

(b): Dindin Abidin, Memet Muhamad, Johansyah Lubis, Ujang Maman, Sudirah (2021). The Effect of Active and Passive Recovery of Weight Training on the Volleyball Smash Performance. International Journal of Human Movement and Sports Sciences, 9(3), 513 - 521. DOI: 10.13189/saj.2021.090317.

Copyright $\odot 2021$ by authors, all rights reserved. Authors agree that this article remains permanently open access under the terms of the Creative Commons Attribution License 4.0 International License

\begin{abstract}
This study aims to examine the effect of the type of weight training with active and passive recovery treatment on the composition of the improvement of volleyball smash technique. This research is a quasi-experiment, with data analysis using SEM-PLS in the weight training model treatment group with active and passive recovery intervals. The subjects of this research were 120 semester IV students of the 2018/2019 Academic Year in the Health and Recreation Study Program, Faculty of Teacher Training and Education (FKIP) UNISMA Bekasi. The measurement results show that the active and passive recovery weight training treatment has a significant effect on the volleyball smash technique skills. The SEM-PLS analysis results show that active recovery weight training improves volleyball smash technique skills $\left(\beta=0.521, \mathrm{~T}_{\text {count }}=5.602 \geq \mathrm{T}_{\text {table }}=2.001, \mathrm{P}-\right.$ Values $=0.000 \leq$ $0.05)$. These findings could assist in adjusting strength training for volleyball player performance enhancement in an effort to improve certain technical abilities, and enable coaches to positively detect people who stand out in volleyball smash speed and accuracy.
\end{abstract}

Keywords Weight Training, Active Recovery, Passive Recovery and Volleyball Smash Technique

\section{Introduction}

The progress of the sport training system should deeply be identified to improve effectively the performance of individual or teams. Most of the interests of the training scope are carried out to achieve flexibility and strength when playing, especially in the form of the most explosive movements of each skill type of sport. The training scheme for each sport is designed as a special long-term process based on the development of solid physical fitness and the ability of the body to react optimally through muscle work. In the world of sports, physical fitness is almost always needed by every athlete and is a serious concern for every coach. Sports experts have agreed that to build physical fitness, an effective method is to use weight training [1]. Weight training is an exercise using weight media that has an effect on improving fitness, muscle strength, speed, muscle tightening, muscle hypertrophy, rehabilitation, weight gain and reduction [2]. Doing weight training requires a systematic process that is repeated or gradual in order to develop speed, strength and endurance as important factors for every athlete [3]. The need for weight training is also an alternative training for volleyball playing techniques which can benefit from forming a good posture including physiological, anatomical, ability and physical health [4]. 
Volleyball is popular all over the world and is a favorite sport, because of the relatively light game, simple technique, uncomplicated rules of the game and very interesting to do [5]. In addition, volleyball has provided a basis for focus as a competitive sport where athletes are required to be professional in providing high performance and coaches continue to seek benefits that can improve performance [6]. To prepare outstanding volleyball athletes at each annual event, the Indonesian Government seeks to provide guidance in applying science and technology, research results or theories about training [7]. The game of volleyball has three main positions, namely the feeder (tosser), libero (defend), and attacker (smash) as a series of determinants who process the ball to get points, but the opposing team will act to block and thwart attacks [8]. In applying the three positions above, a coach must seek to obtain data about effective, influential and dominant training in achieving volleyball skills [9]. Performance in volleyball games really requires a good physical aspect and is trained on every player [10]. The application of weight training is needed to support certain physical elements, especially jumping that dominate volleyball at the moment of attack by doing a smash [11].

The volleyball smash technique is one of the important techniques, it must be mastered as a form of attack, requires high jumps or achievements from the player in order to hit, and directs the ball to the opponent's area to score $[12,13]$. A coach must try to improve volleyball smash skills in order to have a good volleyball team and strive to apply a very effective and efficient training model [7]. Any training for high-performance athletes, such as volleyball players, performs a variety of athletic abilities, including strength, flexibility, agility, and speed for defensive and offensive jumps, blocks, knockouts, and horizontal movements [14]. However, the treatment of recovery time is minimal, so it can cause physiological demands resulting in a potentially negative effect on exercise performance [15]. The optimal level and quality of recovery is very important for high-performing athletes to provide many benefits during training and an important factor in improving the performance of an athlete [16,17]. The recovery process intends to return the body to its initial state or pre-exercise condition, but incomplete recovery results in a state of overtraining syndrome and has a negative impact on various biological functions [18].

Theoretically, improving a successful volleyball smash technique is largely determined by the explosive ability to demonstrate repeated attacks of maximum strength, relatively fast smash rates, precise suggestions, and avoiding the risk of injury appearing while playing [19]. Holmberg [20], based on the results of his research, argues that weight training can help overcome the attributes that underlie performance and reduce the possibility of injury in volleyball. Understanding and mastery of volleyball techniques can be achieved by the method of a weight training program that can support physical attributes as a means of implementing training in the field [21]. According to Supriyanto [22], volleyball players who have a high reaction speed are more efficiently trained using the weight training method. The deficiencies in carrying out current team sports training programs (including volleyball) are not accompanied by a short period of control over recovery and as a result, diverse and demanding training requirements, leading to significant muscle damage and fatigue [23]. Referring to the findings of several previous researchers, the authors are interested in investigating different recovery interventions in weight training performance on their effect on volleyball smash technique. Where active and passive recovery treatment controls are applied in weight training to be able to provide more detailed information about training features, the main output of improving volleyball smash skills, and broadening the scope of knowledge.

\section{Materials and Methods}

\subsection{Research Design}

This study is an experiment to identify the effectiveness of active and passive recovery treatments on weight training performance for increasing smash ability in volleyball. The experiment designs a subject treatment using a static treatment $[24,25]$. This research adopts two subject groups, the experimental group weight training (active recovery) and the control group (passive recovery) (Figure 1). The experimental results are expected to produce new techniques that are useful for training and facilitating players to achieve the expected training results. Weight training procedures and recovery methods are applied to participants without interrupting the daily routine for maximum training performance.

In accordance with the research objectives, this paper attempts to present the effect of weight training performance through active and passive recovery treatments on volleyball smash techniques. Weight training is one type of training to increase the strength and size of the skeletal muscles, especially by using bars, dumbbells and other equipment. In general, weight training is needed for sports such as bodybuilding and weight lifting, but now it is used in many other sports, such as volleyball training to improve athlete performance and reduce the frequency and severity of injuries [26]. Physiologically intensive and high-performance training processes have the potential to cause negative effects. Therefore, this research tries to perform optimal recovery; and it is very important to keep players from high-performance training $[15,16]$. Recovery is an activity carried out after sports activities through an active and passive treatment system [27]. The recovery mode has an inconclusive effect of passive recovery compared to active 
recovery on short-term muscle performance, particularly in improving volleyball smash technique. The cumulative effect of passive and active recovery on muscle performance and dynamic stability is unknown. Therefore, this study aims to prove the performance of weight training through active and passive recovery of volleyball smash techniques. Referring to the weight training method and recovery interval control, this research assumes that the weight training model will be able to facilitate practical application in the development of team sports training programs (including volleyball) [20,23].

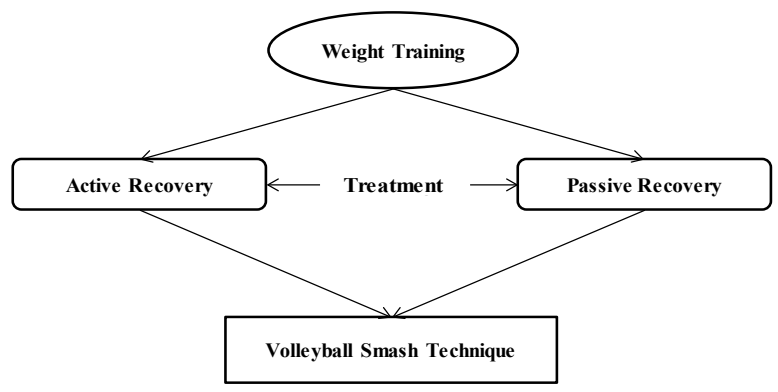

Figure 1. Research Framework Design

\subsection{Subject Selection}

The research was conducted at the Faculty of Teacher Training and Education UNISMA (Islamic University 45) Bekasi, Jl. Cut Mutiah No 83 East Bekasi, Indonesia. The main research subjects were students in semester IV (four) of the 2018/2019 academic year in the Physical Education Study Program for Health and Recreation, FKIP UNISMA Bekasi. Locate and start training in the Volleyball Field and Fitness Room in early May to August 2018. Each student is instructed to perform high intensity training in the weight training process and different recovery methods are applied to them, then the performance level is checked. All students are subject to the same protocol, in which the training is carried out for 8 (eight) weeks with a frequency of three times a week and the total number of meetings is 24 (twenty four) meetings. The duration of experiments or treatments refers to Sutiswo [28] research in a more efficient volleyball training program, which is carried out approximately three times a week. The students were asked not to do any intensity training during the last 24 hours before training for a performance test and they were asked to eat as if preparing for a competition before training. In addition, students were warned not to consume alcohol and stimulants, and advised to pay attention to diet and rest.

\subsection{Sampling Technique}

The target population is 172 students in semester IV (four) of the 2018/2019 Academic Year in the Study Program of Physical Education Study, Health and Recreation, FKIP UNISMA Bekasi, totaling 172 people. Referring to Rono's research [29] if it is not possible to study the entire population but the population is known, the use of sampling techniques can be taken as an alternative to represent the population. Determination of the sample size through the Slovin formula allows researchers to take a small portion of the population at the desired level of accuracy [30]. Determining the sample size using the Slovin formula must be known accuracy the number of population. With a population of 172 people with an error tolerance of $5 \%(\mathrm{n}=$ sample size, $\mathrm{N}=$ total population, $\mathrm{e}=$ fault tolerance), the use of the Slovin formula is as follows:

$$
\begin{aligned}
& \mathrm{n}=\mathrm{N} /\left(1+\mathrm{Ne}^{\wedge} 2\right)=172 /(1+172 \text {. 【0,05】^2) } \\
& =172 /(1+0,43)=172 / 1,43=120 \text { (fulfilled) }
\end{aligned}
$$

Based on the Slovin formula, a sample of 120 people was obtained. Furthermore, the sample was grouped into 2 subjects, namely the experimental group (weight training + active recovery) and the control group (weight training + passive recovery). To determine the experimental group and the control group, the research used a simple random sampling technique with an ordinal pairing system [31], in which the samples randomly are divided into two groups based on the shuffling. The number of samples for each group consisted of 60 students and the treatment was carried out after the students received weight training, then they received treatment based on their groups.

\subsection{Data Analysis}

The data in this research is taken from the assessment of the quality of the volleyball smash ability, namely the average score of the assessment of the speed and accuracy of the smash targets, where each smasher carried out 5 tests and directed to the target box that has been given a score/value and time calculation/seconds from tossing the ball until it falls into the ground/floor, which is analyzed by $\mathrm{T}$-score. Furthermore, the research data were analyzed using the Structural Equation Modeling (SEM) technique with the Partial Least Square (PLS) analysis approach, because in practice, parameter estimation in this method does not require a large sample size and the data does not have to be normally distributed [32, 33, 34]. This research will show data analysis using the SEM-PLS method to prove the relationship between research variables, as well as to measure the direct and indirect effects of one variable on other variables and to analyze patterns of causal relationships between these variables, in which it is shown in the following figure:

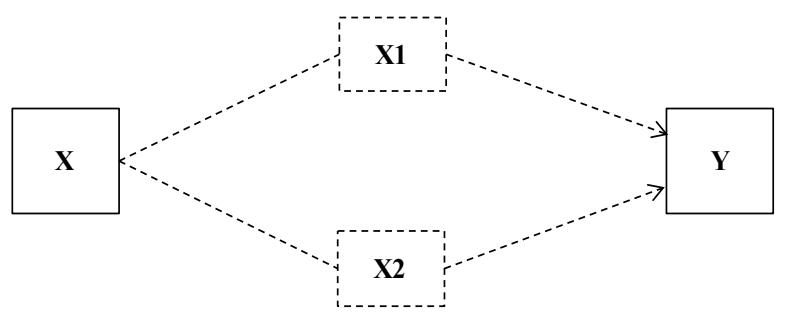

Figure 2. Flow analysis of relationship variables in SEM-PLS Methods 
The SEM-PLS method in path analysis is used to measure the statistical significance and acceptance of the structural modeling identified by the SmartPLS version 3.2.9 for Windows software tools. In addition, the use of the SmartPLS version 3.2.9 software tool is able to calculate how much it supports the significance level of the structural pathway of the influence of variables (X) through treatment $(\mathrm{X} 1 \& \mathrm{X} 2)$ on variables $(\mathrm{Y})$ and calculating the measurement error of each construct that is not observed [35].

\section{Results}

\subsection{Description of Data Distribution}

The average volleyball smash skill score which is the performance of the results of weight training for two sample groups totaling 120 people is presented in Figure 3. Each group of the weight training method was given different treatments, namely active recovery and passive recovery. Weight training testing with active recovery is the focus of this study. In other words, this experimental study intends to prove the effect of weight training with active recovery on volleyball smash skills. Therefore, the respondents who received weight training treatment with active recovery were made into the experimental group; while the respondents who received weight training with passive recovery were made into the control group. The final objective of this experiment is to produce an effective training model for improving volleyball smash skills. The experimental results are expected to be useful for the coach to produce a volleyball team that is skilled, energetic, and has high endurance.

Referring to the data presented in Figure 3, it is known that the treatment of the experimental group model of weight training with active recovery and its effect on the volleyball smash ability based on the average of T-score value has differences with the control group (weight training with passive recovery). More specifically, for the experimental group the test results were scored at sample intervals of $1-10=122.86$, samples $11-20=103.64$, samples $21-30=120.43$, samples $31-40=101.91$, samples 41- $50=122.86$, and samples $51-60=105.83$. To treat the control group model of 60 samples (weight training + passive recovery) on the results of the assessment of the quality of the volleyball smash ability, the average T-score value in the sample interval class is $1-10=94.72$, sample $11-20=84.56$, sample $21-30=90.06$, sample $31-40=81.57$, sample $41-50=81.57$, sample $51-60=$ 90.06. Thus it can be concluded that there is a greater difference in the difference between the value of active recovery weight training and passive recovery weight training group of $12.92 \%$. This session explains the active recovery weight training treatment showed a significant increase in the skill of the volleyball smash technique, and this part of training sessions indicated the reduction of fatigue levels according to the training load and time required to recover.

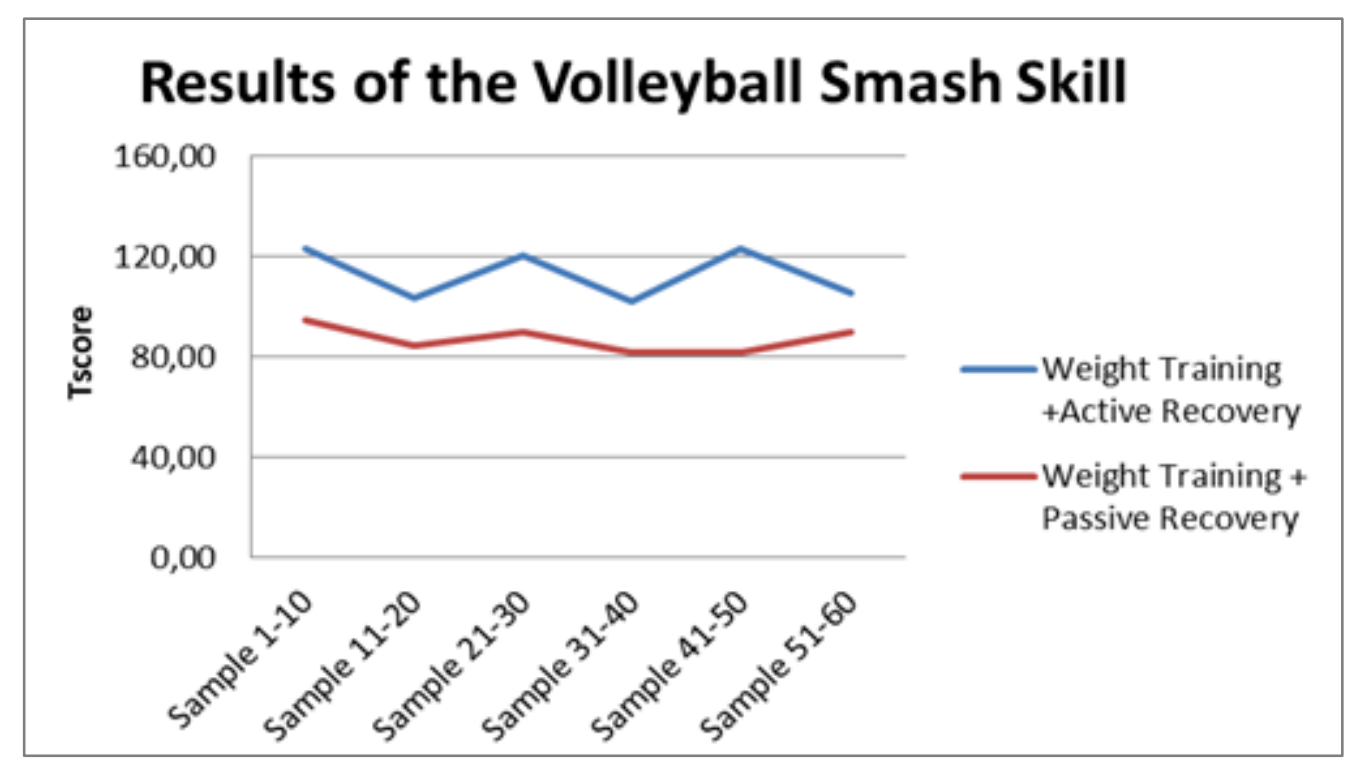

Figure 3. Graph of Volleyball Smash Ability in Experiment and Control Group 


\subsection{Path Analysis Calculations}

In connection with the research data that has been presented previously, the calculation of path analysis in identifying the effect of the treatment of the two group samples, namely the experimental group (weight training + active recovery) and the control group (weight training + passive recovery) should have to be explored. The complete data processing regarding the results of the test performance of the experimental group and the control group and its effect on the volleyball smash ability can be seen based on the calculation of the SmartPLS software tool version 3.2.9 of each variable in following table (Table 1).

By referring to the SEM-PLS calculation model presented in Table 1, the identification of the treatment effect was be furtherly elaborated conceptually by adopting a path analysis model to determine the significance level of the treatment effect on volleyball smash skills based on the value of Path Coefficients, assuming the test is $\geqslant \mathrm{T}$-table and P-Values $\leqslant 0.05$ (Shahid et al., 2020). In the light of this analysis, the experimental group (weight training + active recovery) had a positive and significant effect on volleyball smash ability $(\beta=0.521$, T-count $=5.602 \geqslant \mathrm{~T}$ table $=2.001$, and P-value $=0.000 \leqslant 0.05)$. While the treatment in the control group (weight training + passive recovery) had a positive but insignificant effect on the volleyball smash ability $(\beta=0.189, \mathrm{~T}$-count $=1.833 \leqslant \mathrm{~T}$-table $=2.001$, and P-Values $=0.067 \geqslant 0.05)$. Furthermore, the path analysis measurement model assessment (path coefficient $(\beta)$ is presented in Figure 4 which is reflective/formative.

The estimation results in Figure 4 are considered as sample parameter values that can be used as a reference for getting the effect between variables. In this figure, it is known that the value of the structural coefficient is $\mathrm{X} 1(\beta)$ $=0.521$ and X2 $(\beta)=0.189$. The greater the percentage of the structural coefficient value, the greater the effect of the independent variable in influencing the dependent variable or the smaller the error in predicting the model $[32,33,34]$. Thus, the weight training with an active recovery is a very important and significant factor for improving performance and smash skills of the volleyball players.

Table 1. Calculation Results of the SEM-PLS Method

\begin{tabular}{cccccccc}
\hline & Predictor & & Path Coefficient $(\beta)$ & $\mathrm{T}_{\text {Count }}$ & $\mathrm{T}_{\text {table }}$ & $\mathrm{P}_{\text {Value }}$ & Label \\
\hline $\mathrm{X} 1$ & $-->$ & $\mathrm{Y}$ & 0,521 & 5,602 & 2,001 & 0,000 & Sig. \\
$\mathrm{X} 2$ & $-->$ & $\mathrm{Y}$ & 0,189 & 1,833 & 2,001 & 0,067 & Less sig. \\
\hline
\end{tabular}

Note: * p-values are significant at the 0.05 level

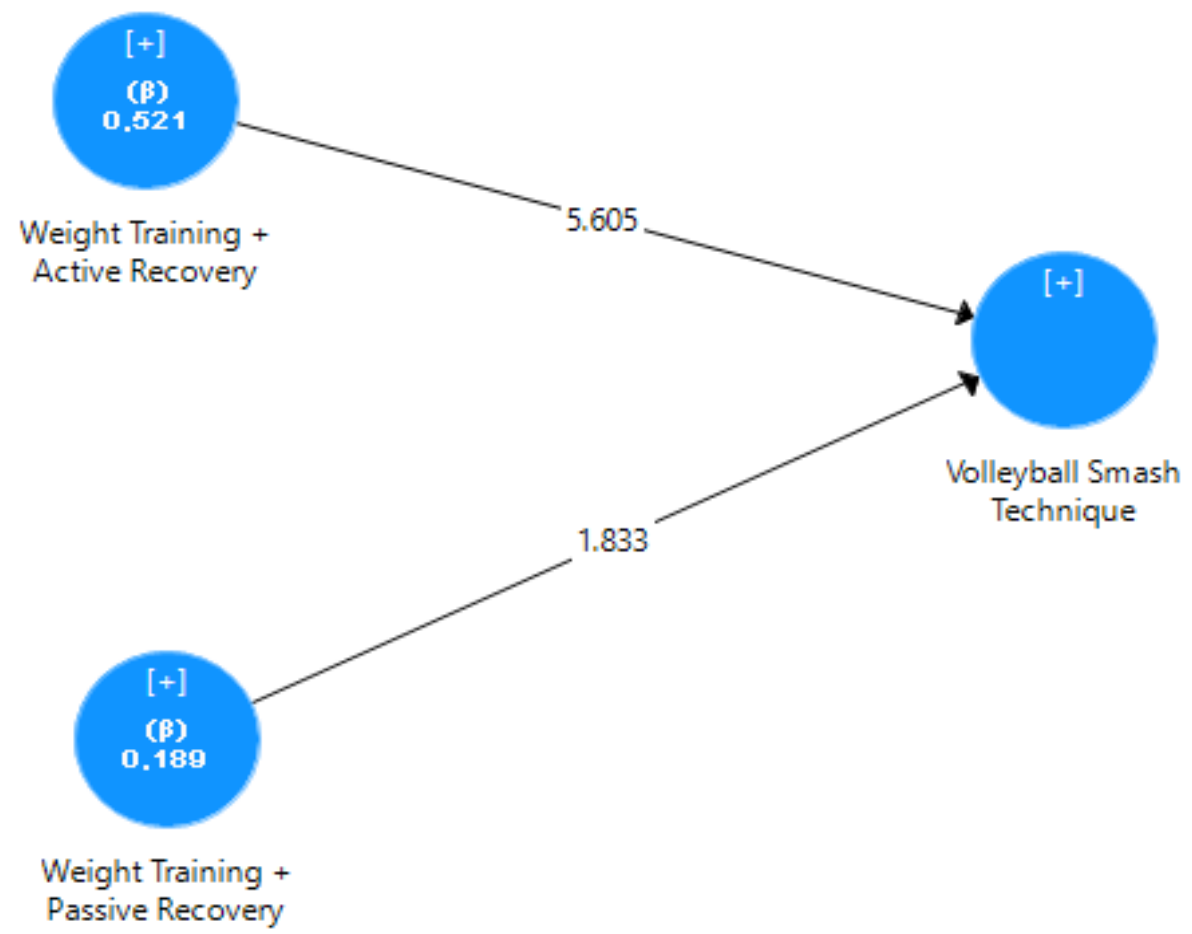

Figure 4. SEM-PLS Structural Data Model on the Relationship between Variables 


\section{Discussion}

For the sportsmen, the goal of training is to improve physical performance. Implementing a training program must balance the intensity and time of rest between competitions [36]. Exercise can affect muscle fatigue which is defined as the loss of muscle strength when over performing or beyond the limits of muscle capacity, fatigue can occur for several minutes, hours or days [37]. Then an unbalanced training program system results in fatigue and poor exercise performance. To avoid fatigue requires recovery time to replenish energy that has been drained during activities. There are two forms of recovery, namely active and passive. The active recovery control is carried out during rest periods, useful in increasing blood flow in muscles, where it can remove lactate and allow phosphocreatine to regenerate [38]. On the other hand, passive recovery is defined as a period of rest that hardly does anything, although the previous studies have described the advantages of this treatment [39].

The adaptation of the volleyball smash training model with the weight training approach to active recovery treatment and passive recovery weight training is described based on field findings which can be explained through descriptive analysis of the frequency of volleyball smash test results and path analysis. Overall, this study found a different result of the volleyball smash technique skills between the active recovery (X1) and the passive recovery (X2) in weight training system. The descriptive data proves a difference of $12.92 \%$ between the two weight training system of active and passive recovery. The results of the volleyball smash technique skills test through active recovery weight training were higher than the volleyball smash technique skill in passive recovery weight training. This means that the active recovery weight training system model indicates the optimal changes in the results of the volleyball smash skills. Using these recovery techniques is equally important for accomplishing training efficiency and it is the most important element of changes in strength performance levels that affect athletes directly [40].

However, in a previous study, Kriel et al. [41] have shown that active recovery is associated with a higher increase in oxygen consumption during exercise compared to passive recovery. In the research of Rey et al. [15] there was no significant difference between active and passive recovery observed in anaerobic performance and lower leg flexibility in professional soccer players, except for the counter movement jump whose posttest scores were significantly greater in the active recovery group than in the passive recovery group. However, the research about the comparison between the active and passive recovery in weight training for the development of volleyball smash skill has not been found yet. Therefore, this research attempts to fill the gap, namely to reveal active and passive recovery treatments in weight training performance on volleyball smash abilities. The study used SEM-PLS analysis to prove the effect of this treatment on volleyball smash technique skills.

This research by adopting the SEM-PLS analysis fortunately showed a significant effect of active recovery weight training treatment with a significant increase in volleyball smash technique skills $\left(\beta=0.521, \mathrm{t}_{\text {count }}=\right.$ $5.602 \geqslant \mathrm{~T}_{\text {table }}=2.001$, value, P-Values $=0.000 \leqslant$ $0.05)$. In this context, referring to the research of Hadi et al. [42], the effectiveness of the weight training method can significantly maximize the increase about $70 \%$ of muscle strength; and of course generally each athlete needs to achieve effective performance by strength training because it involves accumulating muscle mass which requires greater stabilization. The results of our research also prove that volleyball athletes also show a need for a significant increase in strength to improve their performance of playing volleyball. The findings of this study also show that the effect of weight training with active recovery can increase hand muscle strength, both elbow and shoulder joint extension and flexion and can reduce the rate of muscle injury. This discovery is very useful for the development of training models, in particular for improving volleyball smash skills. The coaches or teachers in providing material to athletes or to students can take advantage of the results of this research practically and directly.

The estimation of the value of the sample parameters used to get how much the effect of active recovery weight training performance is known from the structural coefficient value of $\mathrm{X} 1(\beta)=0.521$ or $52.1 \%$. This means that $52.1 \%$ (rounded to $53 \%$ ) the increase in speed and accuracy of volleyball smash techniques is determined by weight training with active recovery. This also shows a small chance of error regarding the effect of active recovery weight training practically to increase the skill of smasher in volleyball play; and it is relevant in which according to Lopes et al. [43] there was a main effect for recovery type, with a lower chance of error $(p<0.05)$ observed for active and passive recovery, where it could be concluded that active recovery significantly resulted in a decrease in lactate concentration and improved power performance at practice. The combination of active recovery weight training also produces many improvements in body quality, such as weight loss, decrease in the percentage of fat, and decrease in waist circumference [44], so that it integrates with the aspect of reducing fatigue levels.

Referring to the research of Mor et al. [40], the active recovery methods have a positive effect on anaerobic strength levels after high-intensity interval training, in which it provides an important alternative to increase the strength - which is one of the most important performance elements in athletes. In line with our research hypothesis, there are differences in the effect of active and passive recovery on the weight training performance of the 
volleyball smash technique. If it is examined more deeply, the active recovery implementation of weight training is more effective as an alternative model of increasing the ability (speed and accuracy) of volleyball smashes, and it strongly indicates the effectiveness of active recovery in weight training system, especially for volleyball players.

\section{Conclusions}

This study shows the importance of re-evaluating the training model that was carried out. As an alternative training model, the results of this study support a weight training program with recovery intervals, because of the significant effect of weight training with active recovery on the improvement of volleyball smash technique skills. The results of this study, of course, become one of the solutions to improve the model of physical fitness to increase the skills of volleyball players; and make it possible for the coach to detect positively stand-out prospective players, who are considered both in terms of the speed and accuracy of the volleyball smash. In addition, the results of this research indicated that active recovery control had the ability to increase fatigue resistance. However, in the future, the results of this study recommend that the trainers always follow the development of research on the efficiency of the volleyball smash technique training model, so that they can carry out further research to obtain better training techniques and models.

\section{Acknowledgements}

The researcher would like to appreciate all those experts for their appropriate and constructive suggestions to improve this research.

\section{REFERENCES}

[1] Suharjana. Analisis Program Kebugaran Jasmani pada Pusat-Pusat Kebugaran di Yogyakarta [Analysis of Physical Fitness Program at Fitness Centers in Yogyakarta]. MEDIKORA, Vol.11, No.2, pp. 135-149, 2013. https://doi.org/10.21831/medikora.v11i2.2813

[2] G. R. R. Soethama, D. Silakarma, I. A. D. Wiryanthini. Pengaruh Latihan Beban Terhadap Peningkatan Massa Otot Pectorals Mayor dan Biceps Pada Remaja dan Dewasa [The Effect of Weight Training on Increased Mass of Major Pectorals and Biceps Muscles in Adolescents and Adults]. Majalah Ilmiah Fisioterapi Indonesia, Vol.4, No.2, pp. 53-57, 2016.https://doi.org/10.24843/MIFI.2016.v04.i02.p0 9

[3] S. Hanafi. Efektifitas Latihan Beban dan Latihan Pliometrik Dalam Meningkatkan Kekuatan Otot Tungkai dan Kecepatan Reaksi [The effectiveness of weight training and plyometric training in creasing leg muscle strength and speed reaction]. Jurnal ILARA, Vol.1, No.2, pp. 1-9, 2010. Accessed from http://digilib.unm.ac.id/files/disk1/7/universitas\%20negeri\% 20makassar-digilib-unm-suriahhana-318-1-1.ibus-h.pdf

[4] Daryono. Pengaruh Latihan Kekuatan Otot Tungkai Terhadap Hasil Smash Peserta Ekstrakurikuler Bola Voli Pendidikan Olah Raga Universitas PGRI Palembang [The Effect of Leg Muscle Strength Training on the Smash Results of Volleyball Extracurricular Participants in Sports Education, PGRI University Palembang]. Jurnal Olympia, Vol.1, No.1, pp. 36-41, 2019. Online available from: https://media.neliti.com/media/publications/283110-pengaru h-latihan-kekuatan-otot-tungkai-t-0449d924.pdf

[5] D. P. Parlindungan. The Effectiveness Of Volleyball Smash Training Model On Imroving Smash Capabilities Of Volleyball Players. Proceeding The 1st International Conference on Social Sciences (ICSS), Vol.1, No.1, pp. 671-676, 2018.

[6] S. L. Halson. Recovery Techniques For Athletes. Sports Science Exchange, Vol.26, No.120, pp. 1-6, 2013. https://secure.footprint.net/gatorade/stg/gssiweb/pdf/120_Re coveryTechniquesforAthletes-Halson_SSE.pdf

[7] Amansyah., Samsudin., M. Asmawi. Training Model Smash Volleyball with Drill Approach. Advances in Health Sciences Research, 1st Unimed International Conference on Sport Science (UnICoSS 2019), Vol. 23, pp. 102-104, 2020. https://doi.org/10.2991/AHSR.K.200305.030

[8] S. Nurfalah, A. S. Hanif, Y. Satyakarnawijaya. Model Latihan Smash Dalam Permainan Bola Voli Untuk Pemula [Smash Training Models In Volleyball Games For Beginners]. Jurnal Pendidikan Olahraga, Vol.8, No.1, pp. 15-26, 2019. http://dx.doi.org/10.31571/jpo.v8i1.1216

[9] R. D. Oktayona, I. Aziz. Tinjauan Kemampuan Teknik Dasar Atlet Bola Voli [Overview of the Basic Technique Ability of Volleyball Athletes]. Jurnal Patriot, Vol.8, No.1, 1259-1273, 2019. https://dx.doi.org/10.24036/patriot.v1i3.418

[10] Muslimin, Moch. Asmawi, Samsudin, F. Dlish, J. Tangkudung, A. Fikri, Destriana. Model Development of Digital Based Volleyball Under Service Skills Instruments. International Journal of Human Movement and Sports Sciences, Vol. 8, No. 6A, pp. 42-46, 2020. DOI: 10.13189/saj.2020.080707.

[11] N. R. Fadhli. Development of a Weight Training Model to Improve the Physical Ability of Volleyball Players (Development Study on Intermediate Level Men's Volleyball Players in Surakarta). Thesis. Program Studi Ilmu Keolahragaan Program Pascasarjana Universitas Sebelas Maret Surakarta, 2013. Online available from: http://staff.uny.ac.id/sites/default/files/PEMBINAAN\%20\% 20FISIK\%20PEBOLAVOLI_0.pdf

[12] M. Suhairi, M. Asmawi, J. Tangkudung, A. S. Hanif, F. Dlis. Development of SMASH Skills Training Model Volleyball Based on Interactive Multimedia. International Journal of Recent Technology and Engineering (IJRTE), Vol.14, No.6, 2774-2781, 2020. https://doi.org/10.3991/ijim.v14i06.13405

[13]K. Vuorinen. Modern volleyball analysis and training periodization. Coaching science follow-up course part 2. Coaching seminar. LBIA028 (VTEA008). Biology of Physical Activity, Finlandia: University of Jyvaskyla, pp.108, 2018. Online available from: https://jyx.jyu.fi/bitstream/han 
dle/123456789/57541/1/Vuorinen\%20Kasper.pdf

[14]H. M. Sahin, H. M. Relationships between acceleration, agility, and jumping ability in female volleyball players. European Journal of Experimental Biology, Vol.4, No.1, pp. 303-308, 2014.

[15]E. Rey, C. Lago - Penas, L. Casais, J. Lago - Ballesteros. The Effect of Immediate Post - Training Active and Passive Recovery Interventions on Anaerobic Performance and Lower Limb Flexibility in Professional Soccer Players. Journal of Human Kinetics, Vol.31, pp. 121 - 129, 2012. Doi: 10.2478/v10078-012-0013-9

[16] S. L. Halson. Recovery Techniques For Athletes. Sports Science Exchange, Vol.26, No.120, pp. 1-6, 2013. https://secure.footprint.net/gatorade/stg/gssiweb/pdf/120_Re coveryTechniquesforAthletes-Halson_SSE.pdf

[17] P. Menzies, C. Menzies, L. McIntyre, P. Paterson, J. Wilson, O. J. Kemi. Blood lactate clearance during active recovery after an intense running bout depends on the intensity of the active recovery. Journal of Sports Sciences, Vol.28, No.9, pp. 975-982, 2010. Doi: 10.1080/02640414.2010.481721

[18] Arifushalat. Pengaruh Recovery Aktif dan Pasif Terhadap Denyut Nadi Pemulihan Pada Atlet Sepak Bola SMA Negeri Keberbakatan Olahraga [The Effect of Active and Passive Recovery on the Pulse of Recovery in Soccer Athletes of the Talented State High School of Sports]. pp. 1-16, 2019. Online from: http://eprints.unm.ac.id/13697/1/JURNAL.pdf

[19] M. Yulianti. Contribution of Leg Muscle Explosive Power and Eye-Hand Coordination to The Accuracy Smash of Athletes in Volleyball Club of Universitas Islam Riau. Journal of Physical Education, Health and Sport, Vol.4, No.2, pp. 70-74, 2017. https://doi.org/10.15294/jpehs.v4i2.1 0571

[20] P. M. Holmberg. Weightlifting to Improve Volleyball Performance. Strength and Conditioning Journal, Vol.35, No.2, p. 79-88, 2013. DOI: 10.1519/SSC.0b013e3182889f4 7.

[21] P. Sutianto, Syafrial., Sofino. Pengaruh Latihan Beban Botol Berpasir Terhadap Kemampuan Service Atas Siswi Peserta Ekstrakurikuler Bola Voli Di SMPN 8 Kota Bengkulu [The Effect of Sand Bottle Weight Training on the Service Ability of Volleyball Extracurricular Participants at SMPN 8 Bengkulu City]. Jurnal Ilmiah Pendidikan Jasmani, Vol.3, No.1, pp. 78-86, 2019. https://doi.org/10.33369/jk.v3i1.8815

[22] Supriyanto. Pengaruh Metode Latihan Plyometric dan Latihan Beban Dengan Kecepatan Reaksi Terhadap Power Otot Tungkai Pemain Bolavoli Putra [The Effect of Plyometric Training Methods and Weight Training with Reaction Speed on the Leg Muscle Power of Men's Volleyball Players]. Gelanggang Olahraga: Jurnal Pendidikan Jasmani dan Olahraga, Vol.2, No.1, pp. 176-189, 2018. https://doi.org/10.31539/jpjo.v2i1.423

[23] J. Calleja-Gonzalez, J. Mielgo-Ayuso, B. Sanchez-Urena, S. M. Ostojic, N. Terrados. Recovery in volleyball. J Sports Med Phys Fitness, Vol.59, No.6, pp. 982-993, 2019. https://doi.org/10.23736/s0022-4707.18.08929-6

[24]A. Bhattacherjee. Social Science Research: Principles, Methods, and Practices, 2nd edition. Florida: University of South Florida, USA, p.1-143, 2012. Online available from: https://scholarcommons.usf.edu/cgi/viewcontent.cgi?article
$=1002 \&$ context $=$ oa textbooks

[25] O. Candra, The Effect of Concentration Training on Shooting Free Throw in Basketball Game. International Journal of Human Movement and Sports Sciences, Vol. 8, No. 6A, pp. 29-35, 2020. DOI: 10.13189/saj.2020.080705.

[26] I. Shaw, B. S. Shaw, G. A. Brown, A. Shariat. Review of the Role of Resistance Training and Musculoskeletal Injury Prevention and Rehabilitation. International Journal of Experimental and Clinical Research, Vol.2016, pp.1-5, 2016.

[27] K. Gogte, P. Srivastav, G. B. Miyaru. Effect of Passive, Active and Combined Warm up on Lower Limb Muscle Performance and Dynamic Stability in Recreational Sports Players. J Clin Diagn Res., Vol.11, No.3, pp. 5-8, 2017. https://doi.org/10.7860/jcdr/2017/24766.9595

[28] Sutiswo. Implemetasi Modifikasi Pembelajaran Lompat Jauh Gaya Jongkok [Implementation of Squat Style Long Jump Learning Modifications]. JSKK: Jurnal Sains Keolahragaan dan Kesehatan, Vol.3, No.2, pp. 46-49, 2018 http://dx.doi.org/10.5614\%2Fjskk. 2018.3.2.6

[29] L. D. C. Rono, L. D. C. Microcredit And Its Relationship To The Growth Of Small and Medium Enterprises In Konoin Subcounty, Kenya. International Journal Of Advanced Research (IJAR), Vol.6, No.4, pp. 961-968, 2018. http://dx.doi.org/10.21474/IJAR01/6935

[30] J. J. Tejada, J. R. B. Punzalan. On the Misuse of Slovin's Formula. The Philippine Statistician, Vol.61, No.1, pp. 129-136, 2012. Online available from: https://www.psai.ph/ docs/publications/tps/tps_2012_61_1_9.pdf

[31]Y. Agustina. The Effect of Weight Training Using Dumbbells on the Under-Service Ability of Volleyball Games in Extracurricular Activities for Girls at SMA Negeri 9 Palembang]. Thesis. Program Studi Pendidikan Jasmani dan Kesehatan Fakultas Keguruan dan Ilmu Pendidikan Universitas Sriwijaya Indralaya, 2016. Online available from: https://repository.unsri.ac.id/16097/1/RAMA 8520106121 006037_0028056101_0012086205_01_font_ref.\%20pdf.pdf

[32] M. Ulum, I. M. Tirta, D. Anggraeni. Analysis of Structural Equation Modeling (SEM) for Small Samples with Partial Least Square (PLS) Approach. Prosiding Seminar Nasional Matematika, Universitas Jember, Vol.1, No.1, pp. 1-15, 2014. https://jurnal.unej.ac.id/index.php/psmp/article/view/934

[33]Z. Jannoo, B. W. Yap, N. Auchoybur, M. A. Lazim. The Effect of Nonnormality on CB-SEM and PLS-SEM Path Estimates. Int. J. Math. Comput. Sci., Vol.8, No.2, pp. 285 291, 2014. DOI: doi.org/10.5281/zenodo.1090631

[34] M. Rozman, P. Tominc, B. Milfelner. A Comparative Study Using Two SEM Techniques on Different Samples Sizes for Determining Factors of Older Employee's Motivation and Satisfaction. Sustainability, Vol.12, No.6, 2189, 2020. https://doi.org/10.3390/su12062189

[35] Sayyida, A. Anekawati. The Use of Structural Equation Modeling (SEM) Analysis in Identifying the Influence of Moderation Variables of Decentralization Structure on the Relationship of Participation in Budgeting and Managerial Performance of SKPD in Sumenep Regency. Prosiding Call For Paper Universitas Wiraraja Sumenep, pp. 63-75, 11 Desember 2012. Online available from: https://www.ejournalwiraraja.com/index.php/PRD/article/vi 
ew/101

[36] J. Hinzpeter, A. Zamorano, D. Cuzmar, M. Lopez, J. Burboa. Effect of active versus passive recovery on performance during intrameet swimming competition. Sports Health, Vol.6, No.2, pp. 119-121, 2014. 10.1177/194173811350076 9

[37] R. Mulyawan. Pengaruh recovery aktif dan pasif terhadap daya tahan otot [Effect of active and passive recovery on muscle endurance]. MEDIKORA: Jurnal Ilmiah Kesehatan Olahraga, Vol.19, No.1, pp. 53-60, 2020. DOI: https://doi.org/10.21831/medikora.v19i1.30886

[38] Y. Shimoyama, T. Wada. Influence of active and passive recovery on physiological responses during rest period in interval swimming. Journal of Sci. and Med. in Sport, Vol.19, pp. 65-66, 2015. https://doi.org/10.1016/j.jsams.2015.12.160

[39] A. B. Abderrahman, H. Zouhal, K. Chamari, D. Thevenet, P.-Y. de Mullenheim, S. Gastinger, Z. Tabka, J. Prioux. Effects of recovery mode (active vs. passive) on performance during a short high-intensity interval training program: a longitudinal study. Eur J Appl Physiol, Vol.113, No.6, pp. 1373-1383, 2013. Doi: 10.1007/s00421-012-2556-9

[40] A. Mor, G. Ipekoglu, C. Arslanoglu, K. Acar, E. Arslanoglu. Effects of Some Active and Passive Recovery Techniques on Strength Parameters. International Journal of Science
Culture and Sport, Vol.5, No.4, pp. 252-262, 2017. https://dergipark.org.tr/tr/download/article-file/396379

[41] Y. Kriel, H. A. Kerherve, C. D. Askew, D. Solomon. The Effect of Active versus Passive Recovery Periods during High Intensity Intermittent Exercise on Local Tissue Oxygenationin 18-30 Year Old Sedentary Men. PLoS One, Vol.11, No.9, 1-20. 2016. doi: 10.1371/journal.pone.016373 3

[42] Hadi., Soegiyanto., S. Rahayu, H. Setiono. Effectiveness of Free Weight Exercise And Super Set Machine System on Strength and Muscle Hypertrophy. Proceedings of the International Conference on Science and Education and Technology 2018 (ISET 2018), 247, 191-195, 2018. https://dx.doi.org/10.2991/iset-18.2018.40

[43] F. A. S. Lopes, V. L. G. Panissa, U. F. Julio, E. M. Menegon, E. Franchini. The Effect of Active Recovery on Power Performance During the Bench Press Exercise. J Hum Kinet., Vol.40, pp.161-169, 2014. DOI: 10.2478/hukin-2014-0018

[44] Padli., Y. Kiram, S. Syahara, H. S. Lesmana. Combined Effects of Weight Training and Aerobic Exercise Accompanied by Normal and Low-Calorie Diets on Fat Percentage of Young Women. International Journal of Human Movement and Sports Sciences Vol.8, No.5, 283-291. 2020. DOI: $10.13189 /$ saj.2020.080517 